\title{
A New Design Proposal for Perforated Solar Screens and Optimization in terms of Solar Control
}

\author{
Fatma Zoroğlu Çağlar*, Gülay Zorer Gedik \\ Faculty of Architecture, Yıldız Technical University, Istanbul, Turkey
}

Received January 15, 2021; Revised May 25, 2021; Accepted October 20, 2021

\section{Cite This Paper in the following Citation Styles}

(a): [1] Fatma Zoroğlu Çağlar, Gülay Zorer Gedik, "A New Design Proposal for Perforated Solar Screens and Optimization in terms of Solar Control," Civil Engineering and Architecture, Vol. 9, No. 7, pp. 2416 - 2426, 2021. DOI: 10.13189/cea.2021.090727.

(b): Fatma Zoroğlu Çağlar, Gülay Zorer Gedik (2021). A New Design Proposal for Perforated Solar Screens and Optimization in terms of Solar Control. Civil Engineering and Architecture, 9(7), 2416 - 2426. DOI: 10.13189/cea.2021.090727.

Copyright@2021 by authors, all rights reserved. Authors agree that this article remains permanently open access under the terms of the Creative Commons Attribution License 4.0 International License

\begin{abstract}
With the use of Perforated Solar Screen (PSS), solar gains are controlled, cooling loads are reduced, and comfort conditions can be achieved while using its energy efficiently. Nowadays, the use of PSS is increased, especially in large, glazed facades. The design of PSS needs to develop and optimize for the temperate humid climate. A new design proposal is presented by considering the basic principles in terms of providing solar control by PSS within the scope of the study. The optimization of the design proposal has been carried out in terms of solar radiation, Annual Sun Exposure (ASE), and View with the use of Rhinoceros/Grasshopper by considering the design variables (angle, perforation ratio, width, and distance, etc.) of the PSS. An optimum design proposal has been presented for the existing classroom (transparency ratio: $60 \%$ ) on the southern facade. Thermal comfort and surface temperature have been calculated. Design proposals can be developed for the west and east facades by using the method of this study.
\end{abstract}

Keywords Perforated Solar Screens, Design Proposal, Solar Control, Parametric Design Optimization

\section{Introduction}

The building envelope separates us from environmental conditions and creates a comfortable interior environment. Especially transparent areas are one of the most important factors affecting indoor comfort conditions because they are the most effective building envelope components in solar gains. The design of transparent areas (transparency ratio, transmission coefficient, and use of solar control devices) is important for the control of solar gains. Today, large glass facades are typical of newly constructed buildings. However, in these designs are not addressed parameters related to visual comfort such as ensuring the level of light, preventing glare and antiglare except for establishing a visual connection with the external environment [1-4]. The high transparency ratios affect thermal and visual comfort conditions negatively.

Solar gain contributes to the cooling load and increases energy consumption in summer [5]; in addition, it has a positive effect in winter. Short wavelengths of solar radiation passing through the glass turn into long waves as a result of contact with the surfaces in the interior and long wavelengths cannot pass through the glass. As a result of these events, a greenhouse effect occurs, and indoor temperature increases. Glazed facades facing west or south (in the northern hemisphere) are particularly vulnerable to overheating, increasing thermal discomfort [6]. Solar radiation passes through the glass, warming the environment and causing thermal discomfort, especially in large, glazed facade buildings.

The amount of energy usage related to artificial light could be reduced with daylight. However, the introduction of daylight is accompanied by solar heat gain. The energy efficiency must be evaluated while accounting for the thermal environment [7]. Some studies carried out have 
shown that energy demanded by overheating has become a recurring problem due to excessive solar gains [8-11] and glare and direct solar gains affect the thermal and visual comfort $[3,11,12]$ in fully glazed facades. Performative façade design can improve the thermal and visual and comfort conditions [13] while reducing energy consumption as the building's skin have an important role in controlling the solar radiation. Building envelope should not be just designed for their aesthetic aspects but also as a functioning element in the building [13]. Solar radiation should be controlled before it gets to the inside of buildings and it is possible with the use of shading devices [3]. Shading devices can block solar radiation before penetrates through the glazing when they are designed on the exterior [14].

The optimum shading devices can improve thermal and visual comfort by controlling solar energy gain and reduce energy consumption. A perforated shading device design is presented in this research with the aim of balancing gains solar radiation. There are several studies on perforated solar screens in the existing literature. These studies related to improving daylight, reduce glare $[3,15]$, improve thermal performance [3] and reduce energy consumption $[3,16]$.

The studies on shading devices are mostly related to office buildings. Providing good environmental conditions for educational buildings is important because of the negative influence of thermal discomfort on students' and teachers' learning/teaching performance and health. Their health and wellbeing depend on an appropriate educational environment $[17,18]$. Also, classrooms in schools are generally large volumes with high occupant density and the number of occupants change instantaneously. Therefore, it is more important to provide comfort conditions in classrooms. An existing classroom was determined as an example with a large number of occupants, and a large volume on the university campus.

The common programs used for analysis in perforated screen studies are energy plus [15,19], Ecotect [20], Grasshopper (Diva [13, 21] and Ladybug, Daysim [3]). Galapagos is an evolutionary solver and is a Genetic
Algorithms (GA) optimization tool used within the platform of the grasshopper and was used to modify and control the different parameters [13]. If there are a large number of problems, GA is used to finding optimized solutions and is a powerful method [3]. Genetic algorithms have been widely used in the built environment research [3,13].

Simulations were conducted using the Rhinoceros/Grasshopper. The optimization of the shading device was carried out with the use of Grasshopper integrated evolutionary optimization tool based on GA.

Within the scope of the study, a new design has been proposed for the use of PSS. The proposed design has been optimized in terms of harmful and helpful solar radiation. As a result of the optimization, the best PSS was optimized again for maximizing view while minimizing annual sun exposure (ASE). The studies in the literature have generally evaluated the PSS in office buildings and in simple terms. In this study, the PSS proposed with an approach different from the previous studies was examined specifically for the classrooms. The PSS proposed by different methods has been optimized. In addition, thermal comfort conditions and inner window surface temperatures have been evaluated according to whether the optimum PSS is used or not.

\section{Methodology}

Istanbul is the province with the highest number of universities, students, and academicians in Turkey. The classroom on the university campus in İstanbul (Lat. $41^{\circ}$ $\mathrm{N}$ and Long. 29 $\mathrm{E}$ ) was selected for investigation. Meteorological data are given in figure 1 for İstanbul (IWEC, 170600) which has a temperate humid climate. Meteorological data show that winters in İstanbul are cold and wet, while summers are hot and humid. The mean sunshine duration is 79,7 (1929-2017) [22] and the sun is rarely seen in winter, while the sky is often cloudless in summer. 

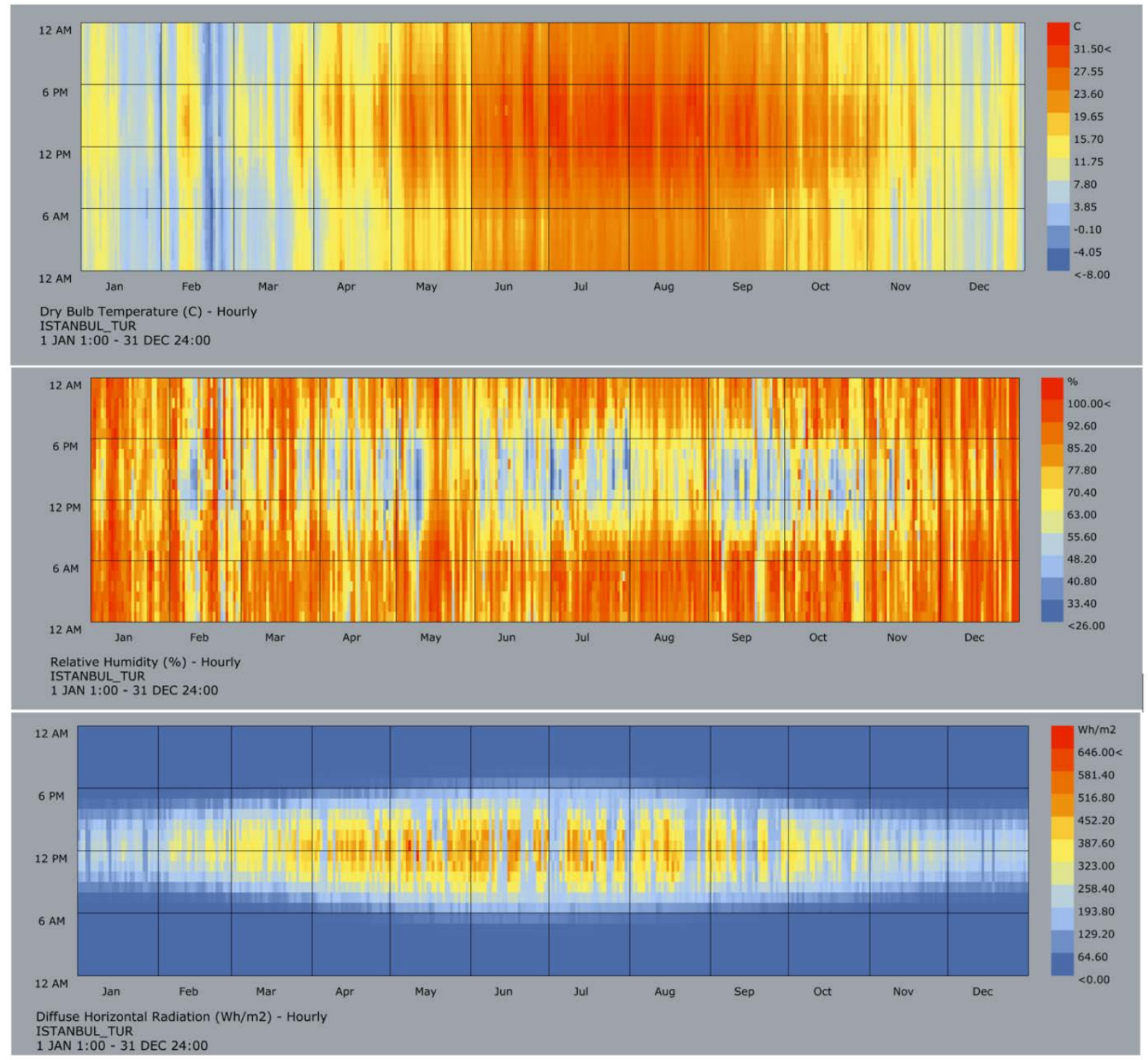

Figure 1. İstanbul monthly Dry Bulb Temperature, Relative Humidity and Horizontal Radiation

The southern facade is the most effective facade in solar gains, thermal and visual comfort. An optimum design proposal has been calculated for the existing classroom on the southern facade. The selected classroom is B 502 and is located in the south (8 degrees from South to West, mentioned as south) of the building on the 5th floor (Fig. 2). There is no obstacle that prevents daylight from the south in the existing classroom.

The classroom is a room is a rectangular plan and a trapezoidal prism $(11,7 \times 8,8 \times(3,1-4,37))$ (Fig. 2). The capacity of the classroom is 109 people. The air conditioning system of the classrooms is natural ventilation and artificial heating. The HVAC system consists of a gas central heating system, Cast 2 iron radiator with open. The window has double-glazed material and the transparency Ratio (WWR - Window to Wall Ratio) is $60 \%$ on the south façade. The light transmittance is determined as \%76 by measurement with Konica Minolta illuminance meter and calculation. The $U$ value of glass is determined as 1,84 $\mathrm{W} / \mathrm{m}^{2} \mathrm{~K}$ and the U-value of the exterior wall determined as $0,38 \mathrm{~W} / \mathrm{m}^{2} \mathrm{~K}$ and interior wall $0,73 \mathrm{~W} / \mathrm{m}^{2} \mathrm{~K}$ by measurement with Testo 635-2.

The volume dimensions, shapes, transparency ratio, and location of transparent areas of these classrooms cause the comfort conditions to be negatively affected. In our previous studies, we determined that the effect of the transparency ratio (WWR) of B-501, B-502, and B-503 classrooms on thermal and visual comfort conditions $[4,23]$. These classrooms were compared in terms of thermal and visual comfort conditions with classrooms in the same direction, nearly the same volume and shape but with different transparency ratios. The high transparency ratio of these classrooms with a south façade negatively affects the comfort conditions. 

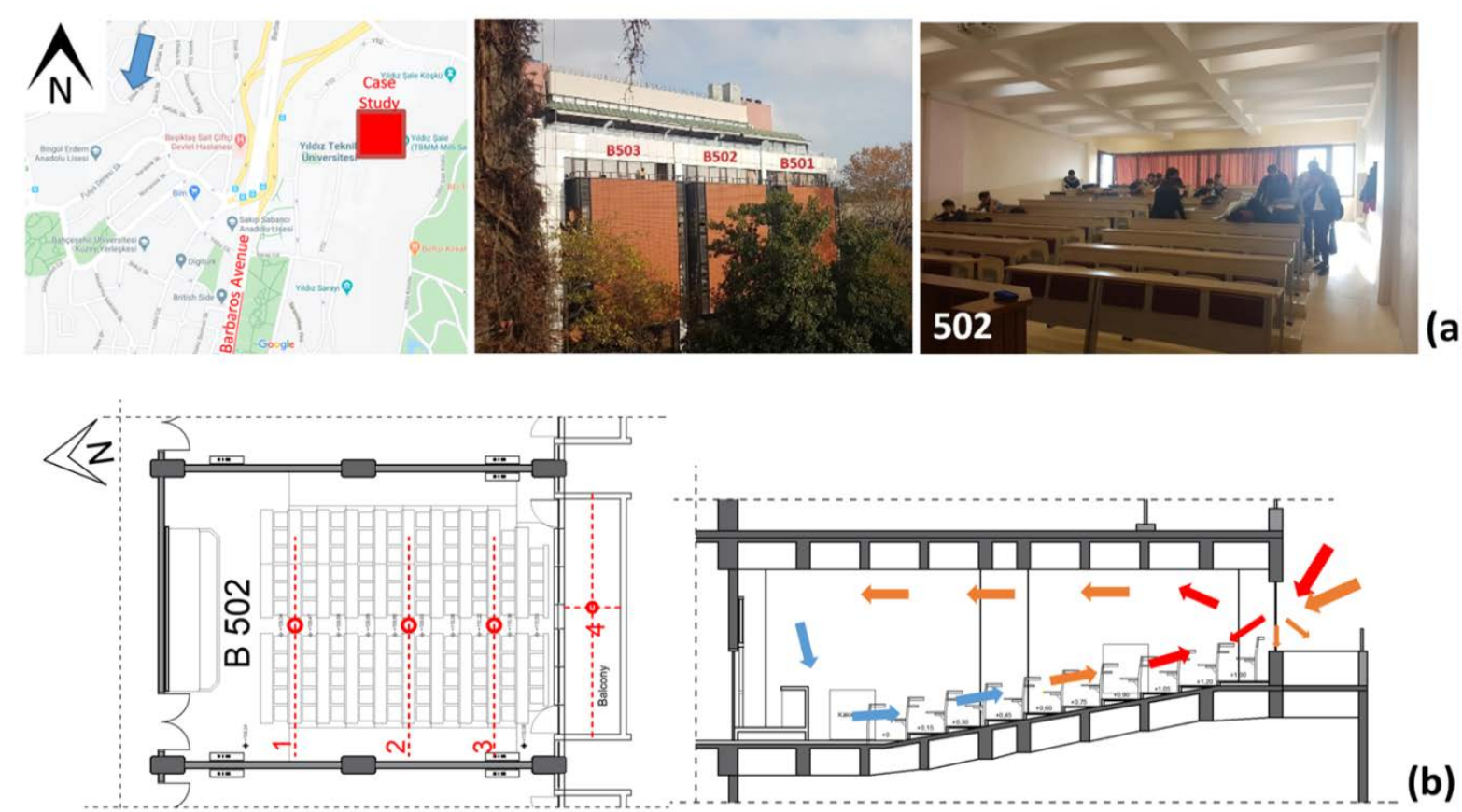

Figure 2. (a) The Location, exterior and interior view of classroom. (b)The plan with measurement points and section of classroom B-502

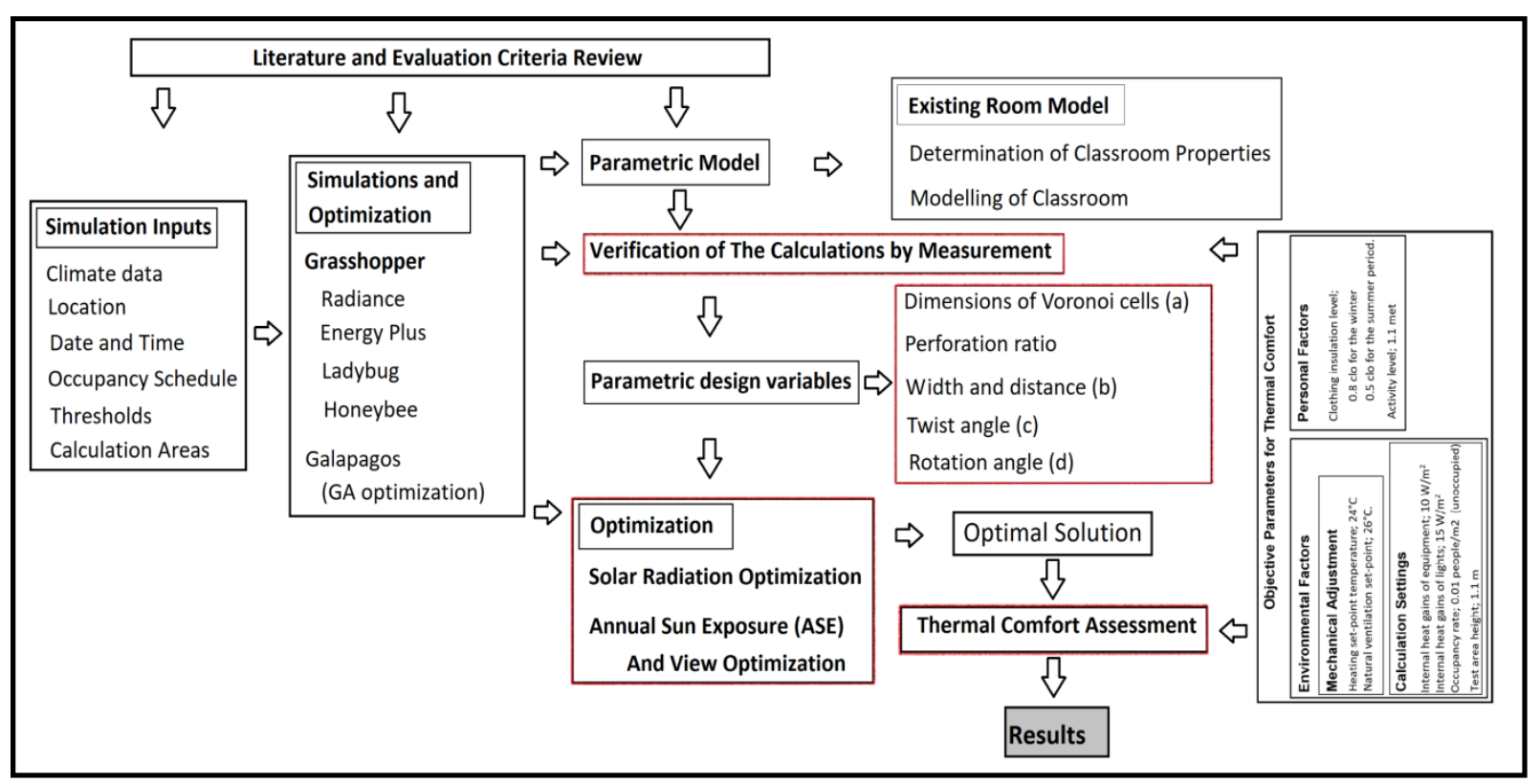

Figure 3. Methodology of the study

\subsection{Simulation and Optimization Methodology}

The existing classroom was modelled using Grasshopper a plug-in for Rhino's 3D modelling tool (Fig. 6). Only the one wall facing south is exposed to the external environment. The window, which is on the south façade, is double-glazed with Air (U-value $1.98 \mathrm{~W} / \mathrm{m}^{2} \mathrm{~K}$, SHGC 0,45, VT 0,76). Simulations use EnergyPlus and Radiance, interfaced with Grasshopper through Ladybug and Honeybee plug-ins. Galapagos is a Genetic Algorithm (GA) optimization tool used within the platform of Grasshopper and was used to modify and control the different parameters. The simulation and optimization methodology of the study is given in figure 3 .

It is important to have an optimum shading device to reduce the solar radiation absorption that leads to an overheated indoor environment and an increase in cooling energy loads [24]. GA was used for optimizing the annual solar radiation performance and sunlight hours and view analysis. The helpful and harmful solar radiation performance was calculated and optimized. The optimizations were made by calculating the solar radiation 
coming to the window surface. The 6th month, the 21st day, the harmful, the 12th month, the 21st day was taken as helpful solar radiation. Optimization has been done so that the harmful radiation is the least and the useful radiation is the highest.

As a result of the solar radiation optimization, the best PSS was optimized again for maximizing view while minimizing annual sun exposure (ASE). The sunlight hours and view optimizations were made for the whole year. The following were determined for this optimization: $1000 \mathrm{~lx}$ daylight threshold, Horizontal 60-degree cone of vision. Sunlight hours are calculated according to $>250$ hours for the calculation surface. The results have been optimized by calculating the percentage according to the area of the calculation surface (The calculation surface is $0.85 \mathrm{~m}$ high from the ground).

The design determined by optimization was analysed in terms of thermal comfort conditions and inner window surface temperature. Measurement results were used to verify the modelling and calculations in the program. Thermal comfort and surface temperature calculations were conducted between 9.00 and 19.00. The calculation months are determined, December representing the winter, July representing the classic summer days, and June and September, when the training continues intensively in the summer months. The existing situation and the optimum situation have been compared in terms of thermal comfort. PMV (Predicted Mean Vote) values obtained as a result of the calculations were evaluated according to the limit values in the ASHRAE 55 standard.

The following adjustments were made for thermal comfort calculations (Fig. 3). The heating set-point temperature is $24^{\circ} \mathrm{C}$, and a natural ventilation setpoint is $26^{\circ} \mathrm{C}$. The clothing insulation level was determined as 0.8 clo for the winter [25] and 0.5 clo for the summer period. The activity level was determined as 1.1 met and the measurement height was determined as $1.1 \mathrm{~m}$ according to the standards [26,27]. Internal heat gains of equipment and lights are $10 \mathrm{~W} / \mathrm{m}^{2}$ and $15 \mathrm{~W} / \mathrm{m}^{2}$, respectively. An occupancy rate of 0.01 people $/ \mathrm{m}^{2}$ for the unoccupied situations.

\subsection{Verification of the Calculations by Measurement}

In order to determine the accuracy of the calculations made in the program, measurements should be verified. Measurements and calculations were made when the classrooms were unoccupied for the existing situation. Thermal comfort measurements were performed on 24.02.2021 with Testo 480 - Digital Temperature and Humidity Meter [28]. While the field study was conducted, the radiators (heating system) and the curtains were opened, and doors were closed. Measurements were conducted while windows were closed and opened. Measurements were made in cloudy sky conditions at 16.00. Measurement results of the outdoor weather conditions: Air Temperature is $12.4^{\circ} \mathrm{C}$, Relative Humidity is $65.4 \%$, and Air Velocity is $1.92 \mathrm{~m} / \mathrm{s}$.

Measurement results were used to verify the modelling and calculations in the program. The measurements were conducted at three points in classrooms (Fig. 2) and calculation results verified according to the average of the values of these points. Measurements and calculations were made at $1.1 \mathrm{~m}$ height, according to 0.8 clo, 1.1 met. The measurements were carried out for 5 minutes at 10 -second intervals at each point after the device was installed and held for 5 minutes. The calculations were made in accordance with the measurement hours, clothing insulation level, activity level, and measurement height. The verifying results are given in figure 4 . Measurements and calculations were made in unoccupied conditions. Our previous study showed that discomfort increased in the warm direction while occupied conditions [23].

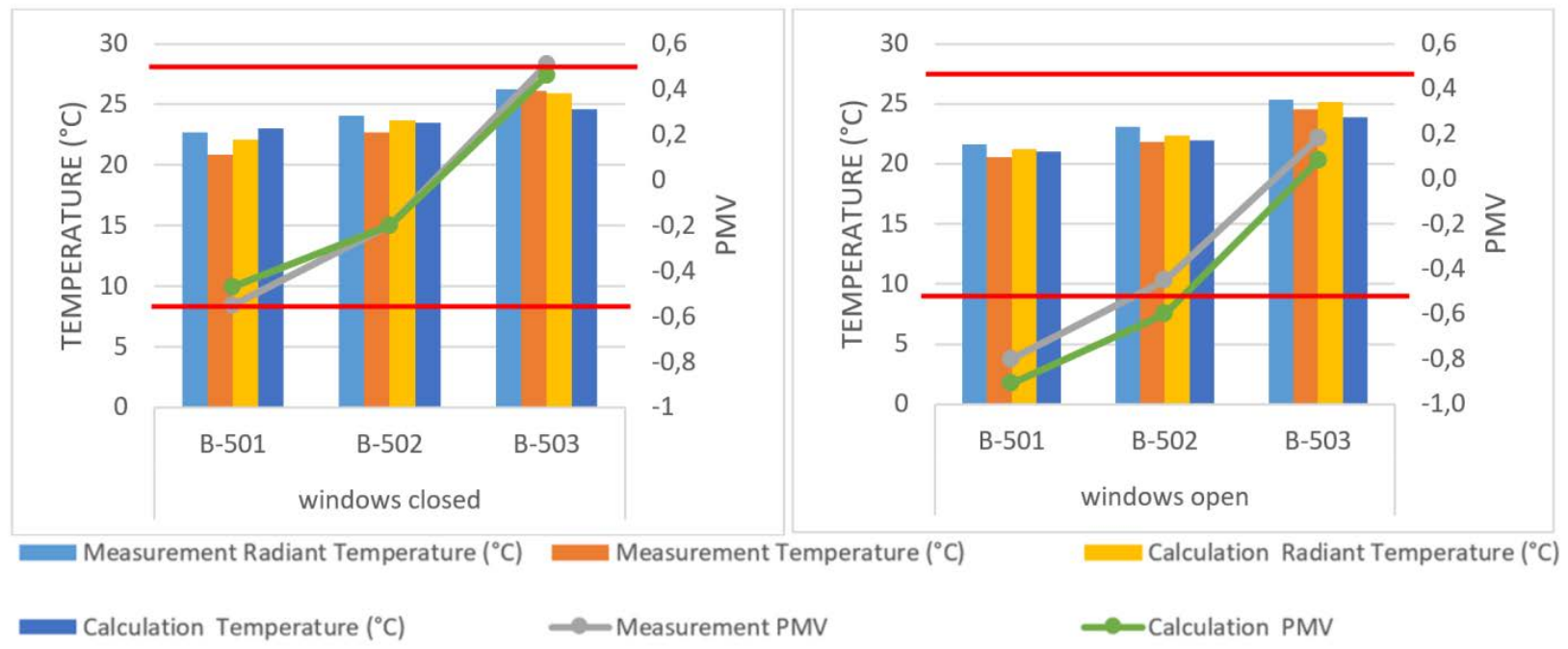

Figure 4. The verification of the calculations by measurement 
Table 1. The Design Parameters

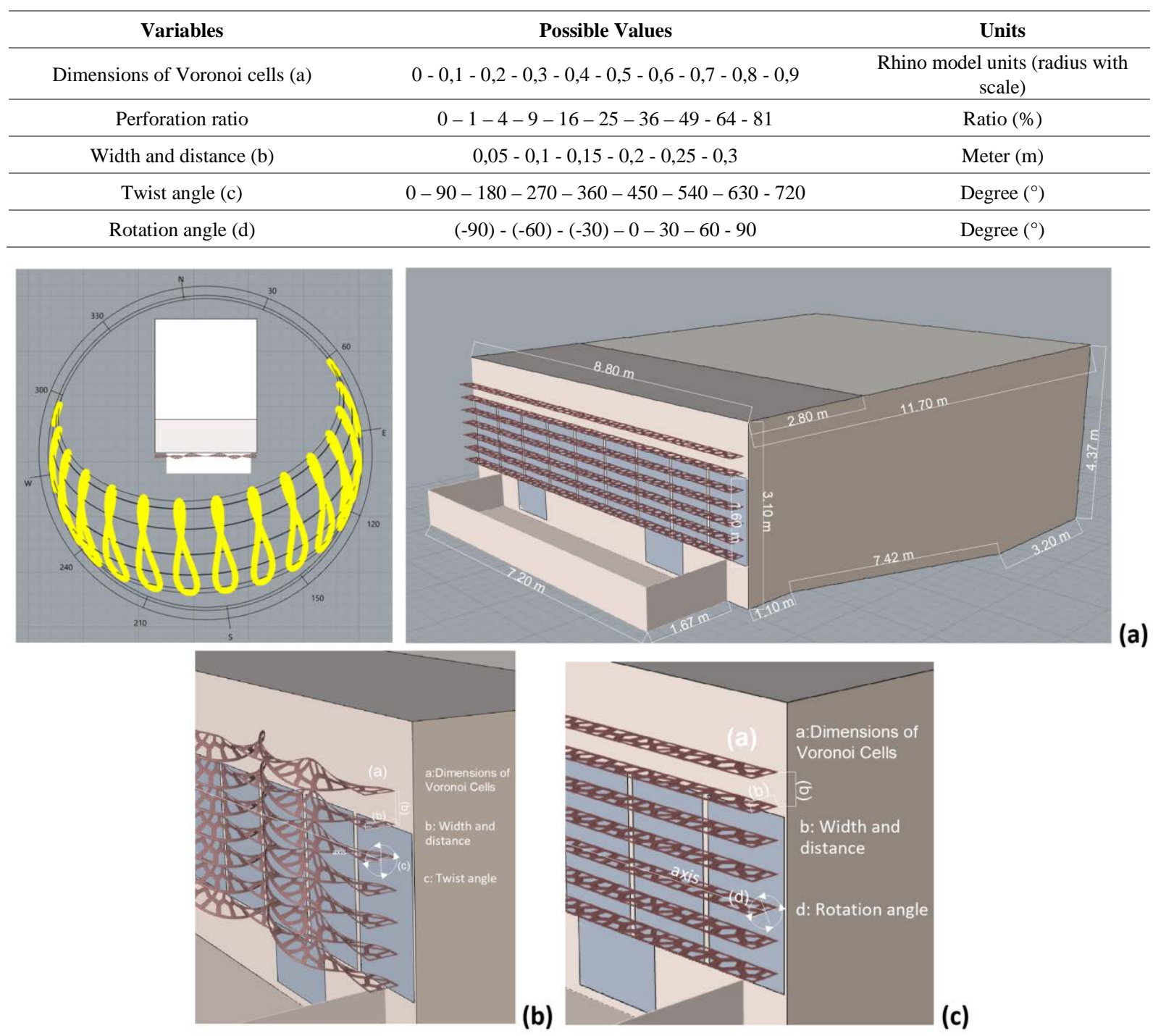

Figure 5. The model of classroom B-502 (a) and PSS geometries with design variables (Twisted PSS (b) - Rotated PSS (c)

\subsection{Design Variables}

A perforated solar screen (PSS) has been modelled at the outside of windows for the optimization analysis. Horizontal shadings were created with Voronoi cells in Grasshopper 3d. The design variables are the dimensions of the Voronoi cells, the width of the horizontal shading devices, the distance between each other, and the twist angle (Fig. 5b). The width of the horizontal geometries is equal to the distance between each other so that they rotate around the axis and do not intersect with each other. The dimensions of the Voronoi cells vary according to different cell radius. Even if the width of the geometry changes, the perforation ratio is the same when the cell dimensions are the same. Different from the specified design variables, the rotation angle was also optimized (Fig. 5c). The rotation angle was optimized for the best result after the first optimization. The positive angles represent the rotating horizontal geometry clockwise. The thickness of the horizontal geometries is set at $0.001 \mathrm{~m}$ and is constant. Figure 5 and Table 1 show the PSS and its variables evaluated. Optimized PSS has been recommended according to all-year use.

\section{Results}

The Twisted PSS has been optimized for helpful and harmful solar radiation. As a result of the optimization, the best PSS was optimized again for maximizing view while minimizing annual sun exposure (ASE). In addition, the best PSS was optimized for solar radiation according to the angle of rotation design variable. The effect of optimized shading devices on thermal comfort conditions has been determined by calculation. In addition, the changes in the inner surface temperature of the windows were also determined. 


\subsection{Optimization Results}

The design variables are optimized according to helpful and harmful solar radiation performance of geometry. The solar radiation optimizations were made for the dates of 21st of June and 21st of December representing the whole year. The sunlight hours and view optimizations were made for the whole year.

\subsubsection{Solar radiation optimization}

First solar radiation optimization was done for twist angle (c), dimensions of Voronoi cells (a), width, and distance (b). Optimization was completed in 53 generations and an optimal solution was obtained in the third generation. The horizontal geometries twisted around its centroidal axis ranging from $0^{\circ}$ to $720^{\circ}$ with $90^{\circ}$ of step. The optimum results were obtained when the twisted angle was $0^{\circ}$ (Table 2). Then, optimization was performed with the rotation angle (d) variable for these geometries perpendicular to the facade. The rotation was done same centroidal axis. $30^{\circ}$ was determined as the best angle as a result of optimization according to the rotation angle variable. $30^{\circ}$ represents the rotating horizontal geometry 30 degrees clockwise. The dimensions of Voronoi cells radius were determined as 0.4 and the width and distance as $0.15 \mathrm{~m}$ for the best Twisted PSS. The optimal solution has $902 \mathrm{kWh} / \mathrm{m}^{2}$ harmful and 1625 $\mathrm{kWh} / \mathrm{m}^{2}$ helpful solar radiation. The PSS rotated 30 degrees clockwise has $1162 \mathrm{kWh} / \mathrm{m}^{2}$ harmful and 1949 $\mathrm{kWh} / \mathrm{m}^{2}$ helpful solar radiation.

Table 2. The solar radiation on the window exterior surface of the existing and best 5 PSS as a result of optimization

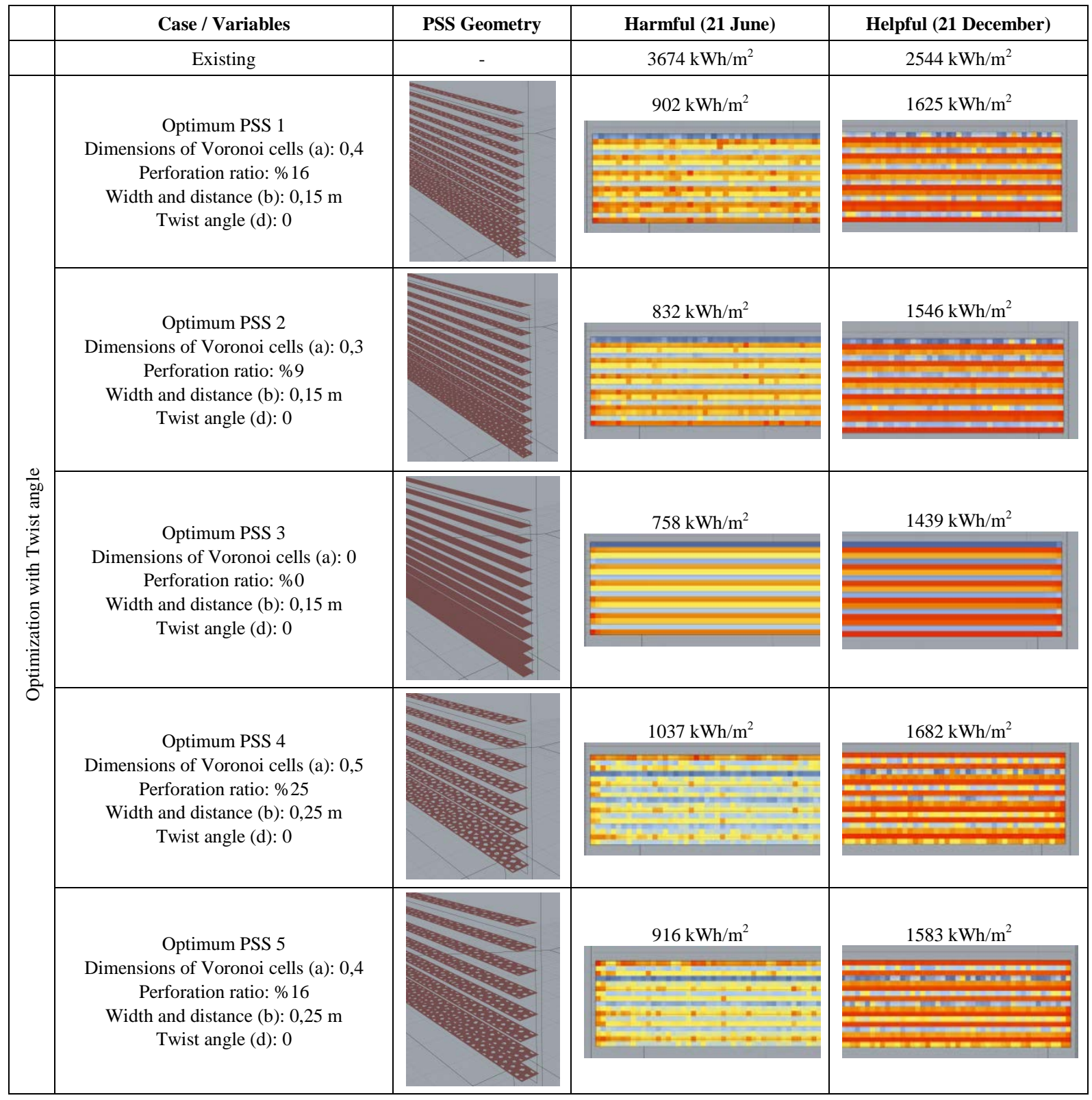




\subsubsection{Annual Sun Exposure (ASE) and View Optimization}

As a result of the solar radiation optimization, view, and annual sun exposure (ASE) optimizations were done for best optimized PSS according to solar radiation. Twist angle (c) was the design variable for this optimization. The best PSS was optimized for maximum view while minimizing annual sun exposure (ASE). The results have been optimized by calculating the percentage according to the area of the calculation surface. The twist angle was determined as $0^{\circ}$ for the best Twisted PSS. According to the result, the best PSS has sunlight over 250 hours on the $17 \%$ of the test area and view is achieved on the $\% 84$ of the test area (Table 3).

Table 3. The Annual Sun Exposure (ASE) An View Factor of the existing and best 3 PSS as a result of optimization

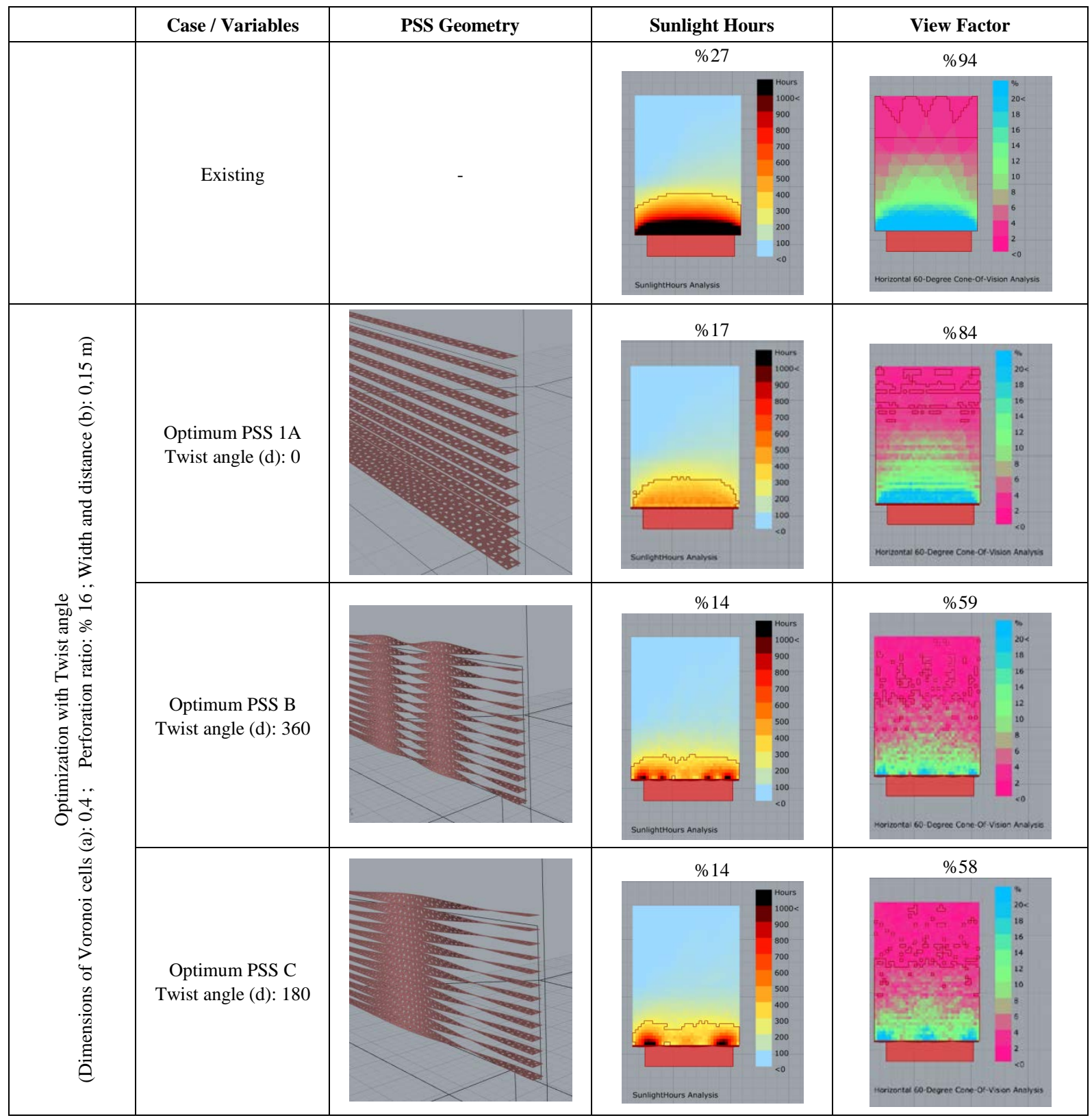


Solar radiation amounts were calculated for the best three PSS determined according to Annual Sun Exposure (ASE) and view optimization. When the twist angle changes, a lower amount of solar radiation was calculated in the summer as determined in the results.

\subsection{Thermal Comfort Assessment of Optimized Model}

Before the thermal comfort analysis, measurement results were used to verify the modelling and calculations in the program. Measurements and calculations were made when the classrooms were unoccupied for the existing situation. Thermal comfort and window inner surface temperatures were determined monthly. The change of indoor thermal comfort conditions was analysed in the case of applying PSS optimized.

It has been calculated that the effect of the PSS, which gives the best result determined by optimization, on thermal comfort and internal surface temperatures. If the determined PSS are used, the thermal comfort conditions have changed positively in comparison with the existing situation. The window inner surface temperatures decreased with the use of PSS. The decrease in window temperatures is higher in the summer months as in thermal comfort (Fig. 6).

Table 4. The Solar radiation of the existing and best 3 PSS as a result of Annual Sun Exposure (ASE) And View Optimization

\begin{tabular}{|c|c|c|c|}
\hline & Case / Variables & Harmful (21 June) & Helpful (21 December) \\
\hline & Existing & $3674 \mathrm{kWh} / \mathrm{m}^{2}$ & $2544 \mathrm{kWh} / \mathrm{m}^{2}$ \\
\hline \multirow{4}{*}{$\begin{array}{l}\text { Optimization with } \\
\text { Twist angle } \\
\text { (Dimensions of } \\
\text { Voronoi cells (a): } \\
0,4 \text {; Perforation } \\
\text { ratio: \%16 ; Width } \\
\text { and distance (b): } \\
0,15 \mathrm{~m} \text { ) }\end{array}$} & & $902 \mathrm{kWh} / \mathrm{m}^{2}$ & $1625 \mathrm{kWh} / \mathrm{m}^{2}$ \\
\hline & $\begin{array}{l}\text { Optimum PSS 1A } \\
\text { Twist angle (d): } 0\end{array}$ & 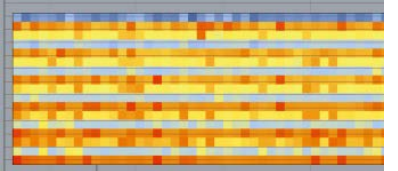 & 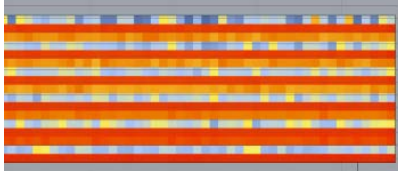 \\
\hline & $\begin{array}{c}\text { Optimum PSS B } \\
\text { Twist angle (d): } 360\end{array}$ & 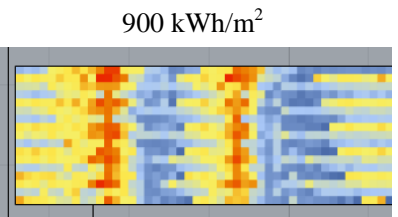 & 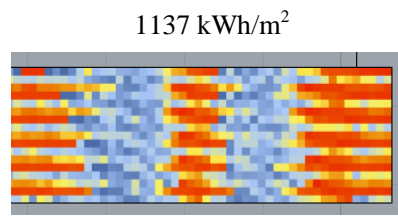 \\
\hline & $\begin{array}{c}\text { Optimum PSS C } \\
\text { Twist angle (d): } 180\end{array}$ & 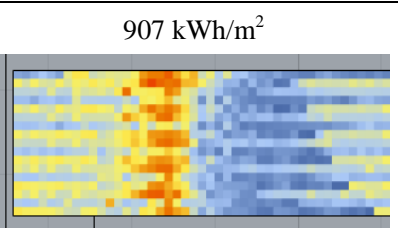 & $1170 \mathrm{kWh} / \mathrm{m}^{2}$ \\
\hline
\end{tabular}

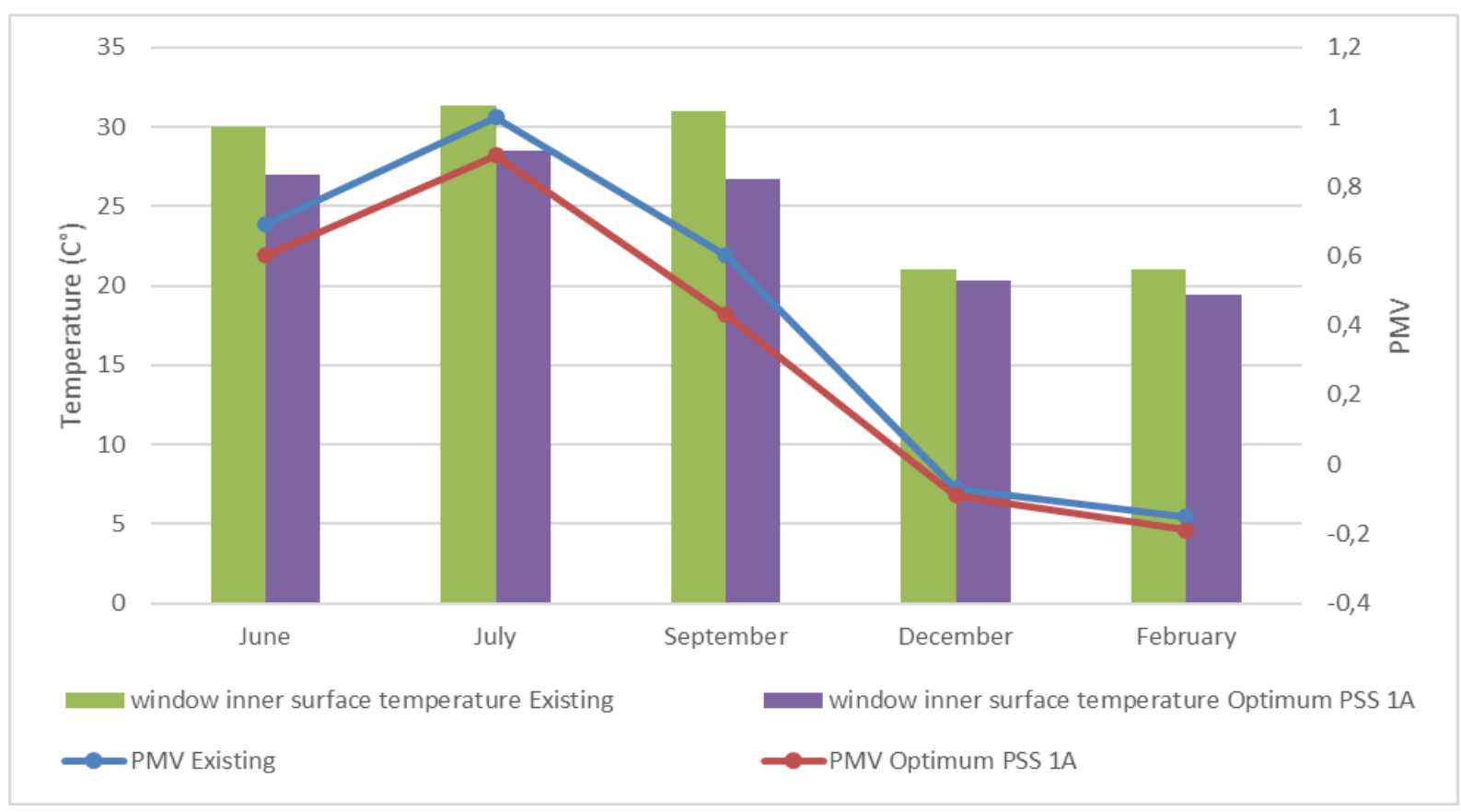

Figure 6. Thermal comfort and window inner surface temperature for situations of existing and with Optimum PSS 


\section{Discussions and Conclusions}

An investigation has been made on the use of PSS on the façade in different ways within the scope of the study. The horizontal PSS geometries twisted and rotated around its centroidal axis. These geometries optimized according to design parameters which the dimensions of Voronoi cells, the width of the horizontal shading devices, the distance between each other, twist, and rotation angle. Optimizations have been done for solar radiation, annual sun exposure and view factor. The best PSS was analyzed in terms of thermal comfort and inner surface temperature after optimizations.

The twist angle was determined as $0^{\circ}$ in optimum results for solar radiation. The $0^{\circ}$ represents the condition that it is positioned perpendicular to the facade. When optimized according to the rotation angle, it has been observed that the best PSS is obtained by rotating the horizontal geometry 30 degrees clockwise.

The solar radiation, view, and annual sun exposure (ASE) optimizations were done for the best optimized PSS. Consequently, it has been observed that the use of 0 -degree horizontal geometries is the best for twist angle design. The other optimum results for the twist angle have been calculated again in terms of solar radiation. When the twist angle changes, a lower amount of solar radiation was calculated in the summer as determined in the results. It has been determined in the thermal comfort calculation results that when the best PSS is used, the thermal comfort in summer has approached the range given in the standards. Thermal comfort remained within the value range given in the standard in winter.

The proposed PSS design is optimized according to all-year use. The method of study can be developed by making additional optimizations according to months as can be seen from the results. It is possible to find and apply optimum results according to months for the PSS suggested in the study. Better results can be obtained if it is designed as kinetic. The proposed designs allow kinetic application. Design proposals can be developed for the east and west facades by using the method of this study. It is necessary to analyze and find the optimum result for the proposed shading device designs to be used in existing or new buildings. Otherwise, the designed shading devices will not be able to perform their original functions.

\section{Acknowledgements}

This paper consists of a part of Fatma Zoroğlu Çağlar's unpublished Ph.D dissertation. This work was supported by Research Fund of the Yildiz Technical University. Project Number: FDK-2021-4165.

\section{REFERENCES}

[1] M. Chandra. Computation of Solar Radiation and Heat Transmission Properties of Glass for Use in Buildings, Architectural Science Review, Vol. 46, No. 2, 175-186, 2003. https://doi.org/10.1080/00038628.2003.9696981

[2] M. Arbab, J. J. Finley. Glass in Architecture, International Journal of Applied Glass Science, Vol. 1, No. 1, 118-129, 2010. https://doi.org/10.1111/j.2041-1294.2010.00004.x

[3] C. Lavin, F. Fiorito. Optimization of an External Perforated Screen for Improved Daylighting and Thermal Performance of an Office Space, Procedia Engineering, 180, 571-581, 2017. https://doi.org/10.1016/j.proeng.2017.04.216

[4] F.Z. Çağlar, A.B. Atmaca, G.Z. Gedik. The Impact of Transparency Ratio on Visual Comfort: A Field Study on Educational Building, In H. A. Nia., (Ed.), New Approaches in Contemporary Architecture and Urbanism (Book Chapter), Chapter 5, 53-60, 2020. https://doi.org/10.38027/N62020ICCAUA316364

[5] J. Apte, D. Arastech. Window-related Energy Consumption in the US Residential and Commercial Building Stock. Lawrence Berkeley National Laboratory (LBNL), Berkeley, CA, 2006. https://doi.org/10.2172/928762

[6] G. Evola, F. Gullo \& L. Marletta. The role of shading devices to improve thermal and visual comfort in existing glazed buildings, Energy Procedia, 134, 2017. 346-355. https://doi.org/10.1016/j.egypro.2017.09.543

[7] C. Ohki, T. Okamoto, J. Tadaki, H. Ohga, N. Yoshizawa. Façade Design Optimization Based on Energy Usage, Glare, and View Using Radiance and Newhasp. 1486-1496, 2019. https://doi.org/10.25039/x46.2019.po145

[8] F. Nicol, M. Wilson, C. Chianccarella. Using field measurements of desktop illuminance in European Offices to investigate its dependence on outdoor conditions and its effects on occupant's satisfaction, and the use of lights and blinds, Energy and Buildings, Vol 38, No 7, 802-8013, 2006. https://doi.org/10.1016/j.enbuild.2006.03.014

[9] K. Konis. Evaluating daylighting effectiveness and occupant visual comfort in a side- lit open-plan office building in San Francisco, California, Building and Environment, Vol 59, 662-677, 2013. https://doi.org/10.10 16/j.buildenv.2012.09.017

[10] S. Grynning, N. Lollli, S. Wagø, B. Risholt. Solar Shading in Low Energy Office Buildings - Design Strategy and User Perception, Journal of Daylighting, Vol 4, 1-14, 2017. http://dx.doi.org/10.15627/jd.2017.1

[11] C. Palarino, M.B. Piderit. Optimisation of passive solar design strategies in side-lit offices: Maximising daylight penetration while reducing the risk of glare in different chilean climate contexts, Journal of Daylighting, Vol 7, No 1, 107-121, 2020. https://doi.org/10.15627/jd.2020.9

[12] M. Bodart, W. Bustamante, F. Encinas. Iluminación Natural de Edificios de Oficina, ARQ, Vol 76, 44-49, 2010. http://dx.doi.org/10.4067/S0717-69962010000300007

[13] M. Gadelhak. Integrating Computational and Building Performance Simulation Techniques for Optimized Facade Designs, In: International Ecaade Conference - Education And Research In Computer Aided Architectural Design In Europe, Vol 2, 261-270, 2013. 
[14] A. Kirimtat, B.K. Koyunbaba, I. Chatzikonstantinou, S. Sariyildiz. Review of simulation modeling for shading devices in buildings, Renewable and Sustainable Energy Reviews, Vol 53, 23-49, 2016. https://doi.org/10.1016/j.rs er.2015.08.020

[15] A. Sherif, H. Sabry, T. Rakha. External perforated Solar Screens for daylighting in residential desert buildings: Identification of minimum perforation percentages. Solar Energy, Vol 86, No 6, 1929-1940, 2012. https://doi.org/10.1016/j.solener.2012.02.029

[16] A. Sherif, A. El-Zafarany, R. Arafa. External perforated window Solar Screens: The effect of screen depth and perforation ratio on energy performance in extreme desert environments, Energy and Buildings, Vol 52, 1-10, 2012. https://doi.org/10.1016/j.enbuild.2012.05.025

[17] J.M. Daisey, W.J. Angell, M.G. Apte. Indoor air quality, ventilation and health symptoms in schools: An analysis of existing information, Indoor Air, Vol 13, 53-64, 2003. https://doi.org/10.1034/j.1600-0668.2003.00153.x

[18] Z. Bakó-Biró, D.J. Clements-Croome, N. Kochhar, H.B. Awbi, M.J. Williams. Ventilation rates in schools and pupils' performance, Building and Environment, Vol 48, 215-223, 2012.https://doi.org/10.1016/j.buildenv.2011.08. 018

[19] J.M. Blanco, A. Buruaga, J. Cuadrado, A. Zapico. Assessment of the influence of façade location and orientation in indoor environment of double-skin building envelopes with perforated metal sheets, Building and Environment, Vol 163, 106325, 2019. https://doi.org/10.1016/j.buildenv.2019.106325

[20] E.M. Alawadhi. Double solar screens for window to control sunlight in Kuwait, Building and Environment, Vol 144, 392-401, 2018.https://doi.org/10.1016/j.buildenv.2018.08. 058

[21] D.A. Chi, D. Moreno, J. Navarro. Design optimization of perforated solar facades in order to balance daylighting with thermal performance, Building and Environment Vol 125, 383-400, 2017. https://doi.org/10.1016/j.buildenv.2017.09. 007

[22] Turkish Republic Ministry of Forestry and Water Affairs. Turkish State, Meteorological Service, General statistical data of our provinces. (in Turkish). 2018. Online available from

https://www.mgm.gov.tr/veridegerlendirme/il-ve-ilceler-ist atistik.aspx?k=A\&m=ISTANBUL , (accessed 2018).

[23] F.Z. Çağlar, G.Z. Gedik, H. Gökdemir. The impact of transparency ratio on thermal comfort: A field study on educational building, Civil Engineering and Architecture, Vol 8, No, 5, 890-897, 2020. https://doi.org/10.13189/cea. 2020.080516

[24] N.A. Al-Tamimi, S.F.S. Fadzil. The potential of shading devices for temperature reduction in high-rise residential buildings in the tropics, Procedia Engineering, Vol 21, 273-282, 2011. https://doi.org/10.1016/j.proeng.2011.11.2 015

[25] F. Zoroğlu. An evaluation of thermal comfort conditions and energy consumption of the shopping malls, Master Thesis, Y1ld1z Technical University, Istanbul, 2017.

[26] ANSI/ASHRAE Standard 55: 2017. Thermal Environmental Conditions for Human Occupancy. American Society of Heating, Refrigerating and Air-Conditioning Engineers, 2017.

[27] BS EN ISO 7730: 2005. Ergonomics of the thermal environment - Analytical determination and interpretation of thermal comfort using calculation of the PMV and PPD indices and local thermal comfort criteria. International Standardization Organization, Britısh Standard, 2005.

[28] Testo 480-Digital Temperature and Humidity Meter. Multi-function VAC measuring instrument, Multi-function VAC measuring instrument. testo 480 - Cutting-edge technology for professionals, Product Brochures, 2019. 